\title{
Communication
}

\section{Design of a Smart System for Rapid Bacterial Test}

\author{
Rajshree Patil ${ }^{1}$, Saurabh Levin ${ }^{2}$, Samuel Rajkumar ${ }^{2}$ and Tahmina Ajmal ${ }^{3, *}$ \\ 1 Institute of Chemical Technology (ICT), Matunga, Mumbai 400019, India; rajshree@ffem.io \\ 2 Foundation for Environmental Monitoring, Shivajinagar, Bangalore 560001, India; saurabh@ffem.io (S.L.); \\ srajkumar@ffem.io (S.R.) \\ 3 School of Computer Science and Technology, University of Bedfordshire, Luton LU1 3J, UK \\ * Correspondence: Tahmina.Ajmal@beds.ac.uk
}

Received: 18 November 2019; Accepted: 15 December 2019; Published: 19 December 2019

check for updates

\begin{abstract}
In this article, we present our initial findings to support the design of an advanced field test to detect bacterial contamination in water samples. The system combines the use of image processing and neural networks to detect an early presence of bacterial activity. We present here a proof of concept with some tests results. Our initial findings are very promising and indicate detection of viable bacterial cells within a period of $2 \mathrm{~h}$. To the authors' knowledge this is the first attempt to quantify viable bacterial cells in a water sample using cell splitting. We also present a detailed design of the complete system that uses the time lapse images from a microscope to complete the design of a neural network based smart system.
\end{abstract}

Keywords: microscope; bacterial contamination; water contamination; artificial intelligence

\section{Introduction}

Microbial contamination of drinking water is a daunting challenge that has severe impacts on human health [1]. According to the World Health Organization (WHO) statistics in 2017, 785 million people lack even a basic drinking water service, including 144 million people who are dependent on surface water. In India alone, annually around 37.7 million people are affected by waterborne diseases which result in 1.5 million child deaths due to diarrhea [2-4]. For the past few decades, across the world various organizations-governments, non-governmental organizations (NGOs), scientists-are actively working to understand the challenges and provide a sustainable solution for supply water fit for human consumption [5-7]. One of the United Nations' Sustainable Development Goals is "By 2030, achieve universal and equitable access to safe and affordable drinking water for all" [8]. The first step in these efforts is to get an accurate assessment of the water quality for the presence of bacterial contamination. Bacteria like Escherichia coli (E. coli), which has been universally accepted as an indicator of fecal contamination, forms a useful indicator of microbial water contamination [9,10]. The basic concept of using coliforms as indicator bacteria is due to its abundance in the feces of humans and other warm-blooded animals. If fecal pollution has entered drinking water, it is likely that these bacteria will be present even after significant dilution. Thus, the presence of pathogens is determined with indirect evidence by testing for indicator organisms such as coliform bacteria which is from the same source of pathogenic bacteria. Moreover, monitoring these indicator bacteria is safe, easy, and economical as compared to other pathogens [11].

However, the tests for detecting the presence of coliforms, like any other bacterial contaminant, takes 24 to $48 \mathrm{~h}$ for confirmation and requires a degree of technical expertise [12]. This duration is long for any remedial action to have an effect and this delay results in a rapid spread of disease. Moreover, these methods require transportation of samples to laboratories, which can be challenging in remote locations [13]. Thus, there is an urgent need for a rapid method for on-site detection and to 
simultaneously communicate contamination in drinking water. Most of the methods $[14,15]$ rely on allowing the growth of bacteria in selective growth mediators in the presence of a specific substrate which atleast requires $24 \mathrm{~h}$; then they quantify the resulting growth by an indication of gradients of turbidity or color in a liquid media which could be detected visually, or by using a photometer or camera. Alternatively, these can also be quantified as visible detectable colonies on a solid media, giving estimates of viable bacteria in the sample. These standard methods are bounded by some theoretical limitations in terms of the time needed to detect the results. These methods [16] can sense cell density only when the population reaches $10^{6}$ to $10^{7} \mathrm{CFU} / \mathrm{mL}$ (colony forming unit) per milliliter. The molecular biology methods, such as PCR [17,18], are exorbitantly expensive, require trained personal, and still need at least $4-6 \mathrm{~h}$ for data interpretation. Direct observation of microbial contaminants using microscopy, which is one of the oldest methods of detecting bacterial cells at the single cell level, can provide a solution. The bacterial identification method uses differential staining procedure for classifying bacteria in different groups (e.g., gram positive or gram negative, cocci or rods, etc.). However, despite its tremendous potential of direct observation of bacterial cells under the microscope, the method is not used extensively for monitoring indicator bacterial pathogens such as coliform in water bodies for two reasons: it requires a trained eye and it does not discriminate between living and dead cells.

Similarly, application of high-throughput microscopy such as atomic force and optical microscopy are commonly used method for monitoring bacterial division at the single cell level. This requires immobilizing cells via some means of physical attachment such as agarose gel or within polydimethylsiloxane (PDMS)-based microfluidic channels $[19,20]$. Physical attachment is required to confine the cells movement so these can be observed under the microscope. PDMS is usually used to develop microfluidic devices using microfabrication techniques. However, PDMS microfluidic devices are complicated to fabricate and expensive. Use of agarose gel is the inexpensive way to immobilize cells where the cells are trapped between a thin layer of agarose and a transparent glass slide or coverslip. The function of agarose is similar to that of agar powder most commonly used in microbiological growth media as a solidifying agent where growth media can also act as a source of nutrients for the immobilized cells. However, such a system gets dehydrated rapidly due to the evaporation of moisture and thus becomes disturbed in a short span of time.

The other major disadvantage of the simple microscopic method is that the morphological features of bacteria observed under the microscope may not be sufficient for specific identification of bacteria. However, with advances in fluorescence microscopy and by using different vital dyes, such as propidium iodide, it is possible to differentiate between viable and non-viable bacterial cells [21,22]. These dyes are also instrumental in eliminating interference of any physical contamination. Epifluorescence microscopy can be used to rapidly estimate total cell numbers in water samples by using dyes, such as 4,6-diamidino-2-phenylindole dihydrochloride, acridine orange, and SYBR Green I (SG), that bind to nucleic acids which differentiate between live and dead bacteria. In these techniques, specificity of bacterial detection can be achieved by using specific probes such as $16 \mathrm{~s}$, rRNA probe, antibodies or aptamers specific for target bacterial population [23,24]. However, the regents and the cost of the instrument involved are very high [25].

Another limitation of the microscopy-based method is the low sample volume that can be used for analysis (at microliter level), hence this doesnot meet the WHO recommended limit of detection (i.e., $1 \mathrm{CFU} / 100 \mathrm{~mL}$ of sample) [26]. Concentration of bacteria from a large volume of water using membrane filtration and back elution in a small volume of water is one of the possible approaches to enhance the detection limit of microscopic observation [27].

The common factor between all bacterial measurement approaches is detection of viable bacterial cells under favorable growth conditions. In this work, we propose a method which still uses the traditional method of filtration to condense the amount of fluid and then specific growth media is used for bacteria cells to multiply. The proposed smart system uses a microscope lens together with a camera to observe their multiplication. The novelty of the idea is the capability to capture the splitting 
events (binary fission) of bacteria which usually occur in 30-60-min intervals if the cells are alive and surrounded by favorable conditions of growth (e.g., nutrient and temperature). Thus, here detection is carried out at a single cell level, which could occur within 1-2 h unlike in conventional methods that detect the bacterial population after a lengthy incubation period of $24-72 \mathrm{~h}$. The concept is to immobilize concentrated bacterial cells in a small volume of media that are then continuously observed and recorded. Since bacteria are immobilized in a very small area the probability of observing bacteria under the field of view of microscope increases many folds as compared to the traditional turbidimetric method of sensing bacteria. The turbidimetric method requires that the bacterial growth reach at least $10^{6}-10^{7}$ cells/mL to visibly detect their presence, whereas a bacterial growth of less than $100 \mathrm{CFU} / \mathrm{mL}$ can be observed under the microscope. Since this method is based on capturing the splitting event of bacteria, the dead cells present under the microscopic view are naturally eliminated in the detection process. Our initial findings indicate that an initial bacterial concentration of $1-10 \mathrm{CFU} / \mathrm{mL}$ can be detected within a 1-2 h window. In this study, we used Escherichia coli (E. coli) as a means of interest in water contamination monitoring. However, the methods used can be applied to other bacteria also with suitable changes.

\section{Materials and Methods}

\section{Live-Cell Imaging of Bacteria}

Escherichia coli NCIM 2277 obtained from National Culture Collection of Industrial Microorganisms (NCIM), Pune, India was used in this study. The stock suspension of bacteria was prepared by growing the bacterial strains in A1 agar (HiMedia ${ }^{\circledR}$ Laboratories, Mumbai, India) at $37^{\circ} \mathrm{C}$ for $24 \mathrm{~h}$. The grown cells were washed off using normal saline $(0.85 \%$ sodium chloride in distilled water) and pelleted out by centrifugation at $6000 \mathrm{rpm}$ for $10 \mathrm{~min}$. The pellet washing procedure was repeated twice by centrifugation for $5 \mathrm{~min}$ using normal saline. The cell density of the culture was adjusted to obtain a final cell concentration in the range of $10^{1}-10^{2} \mathrm{CFU} / \mathrm{mL}$. During the test diluted stock cell suspension was used for preparing test water contaminated with $10 \mathrm{CFU} / \mathrm{mL}$ of E. coli. The experimental procedure involves filtering $100 \mathrm{~mL}$ of artificially contaminated water sample through a sterile $0.45 \mu \mathrm{m}$ membrane filter (Millipore, Bangalore, India). After filtration the bacterial cells trapped on the membrane filter were eluted back in $1 \mathrm{~mL}$ of sterile coliform specific growth media (i.e., Rapid HiColiform broth) (HiMedia ${ }^{\circledR}$ Laboratories, Mumbai, India). The presence of sodium lauryl sulphate makes the medium selective for coliform by inhibiting accompanying microflora, especially the gram-positive organisms. The trapped cells were then transferred in an Eppendorf tube of $2 \mathrm{~mL}$ capacity. Thus, now the concentration of bacteria per $\mathrm{mL}$ of sample increases to 100 fold to that of the original concentration. To $0.5 \mathrm{~mL}$ of this suspension, $0.5 \mathrm{~mL}$ of coliform specific agar media (containing $1 \%$ of agar) is added and mixed thoroughly. Before the mixture gets solidified it was loaded in-between the coverslip place on the graded area of the counting chamber so as to form a thin film of solid layer of immobilized bacterial cell below the coverslip. To prevent dehydration of this film a liquid growth medium was added to the side trough. The open end of the trough at four corners was sealed using araldite to prevent leakage of the liquid media before loading the slide. A heating pad was attached to the slide to create a warm environment which is required for optimal growth of bacteria. The heating pad consists of a heating element (resistive heating pad by SparkFun Electronics, Bangalore, India ${ }^{\circledR}$ was used here). A microcontroller-based thermostat was placed in a small plastic box to maintain the optimum multiplication for the target bacteria, typically this is either $37^{\circ} \mathrm{C}$ or $44^{\circ} \mathrm{C}$. The system was powered by a $9 \mathrm{~V}$ standard battery that supplies $9 \mathrm{~V} / 1 \mathrm{Amp}$ to maintain the required temperature. The temperature can be set to $37^{\circ} \mathrm{C}$ and itvaries \pm 2 around the target value due to periodic on/off of the heating pad by the microcontroller. The temperature was controlled by the thermistor reading and three light-emitting diodes (LEDs) (red, blue, and yellow) are placed to give a visual indication of temperature. When the set-up starts, all the three LEDs, were in the on position; later on when the system stabilizes only one LED was on depending on temperature. A red LED indicates that temperature is higher than 
set, blue LED indicates when temperature is lower than set value, and yellow LED indicates normal functioning. The slide was fixed under the microscope (Labomed Lx 300i) and observed under $40 \times$ objective lens viewed using the camera (MICAPS, FERLAF, FO50). The bacterial multiplication was continuously recorded by using the auto capture tool at regular intervals of time. A schematic diagram of the microscope setup is shown below in Figure 1 together with two photographs of the experimental setup.
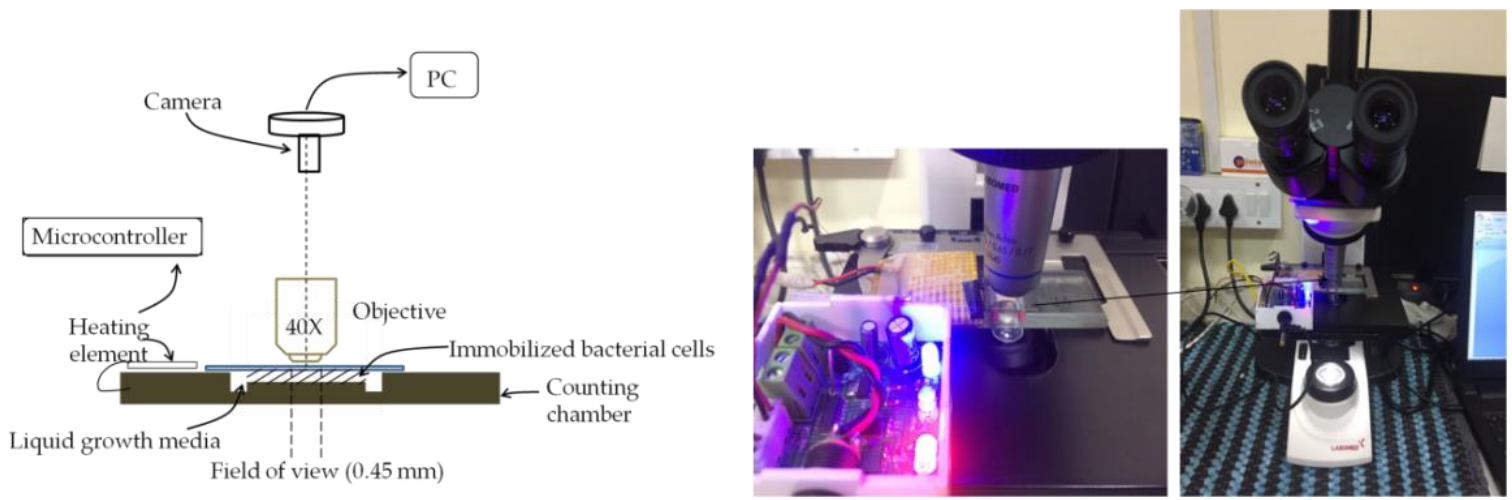

Figure 1. Experimental setup for observing bacterial multiplication.

The bacterial multiplication can be evaluated by observing any change in bacterial cell numbers or absolute change in elongation or movement of individual bacterial cells or their chain relative to a fixed reference point. The grids present on the counting chamber were used as a reference point because they remained stable on the final images.

\section{Results and Discussion}

Our aim is to develop a simple and rapid method for detection of bacteria in water samples by combining a traditional culture-based detection method and simple bright field microscopy. The idea is to reduce the detection time by using microscope so that an observation can be made at the single cell level. Immobilization of bacteria in the specific growth media on the surface of a specialized slide captured the growth pattern of single bacteria under the microscope. Figure 2 shows multiplication events over a period of $4 \mathrm{~h}$ with an initial concentration of bacterial cells in a water sample of $10 \mathrm{CFU} / \mathrm{mL}$. During the experiment the immobilized agar layer did not show signs of desiccation and was thin enough to facilitate the exchange of air required for $E$. coli.

As seen in the Figure 2, in the initial image at 0:00 (H:min) no specific form of bacterial shape can be identified and only a few dark dots can be seen distributed on the surface. After 20 min one of the dark spots indicated by an arrow in the image started elongating and acquiring a distinct shape. In-between 40-50 min a recognizable shape of bacteria appears in the image. The 1:00 h image shows initiation of the splitting event and at 1:20 h, a complete splitting of bacteria in two distinct halves can be seen. This splitting time is considered as an evidence of the presence of viable bacteriain the water sample. As seen in Figure 2, all the images after 1:20 clearly show the multiplication of bacteria within an aggregate and the size of the lumps start increasing. At the end of 4:00 h the form is clearly identifiable and has a distinct morphology and clear movement. The time required to clearly distinguish the bacteria shape from other spots present in the initial image is $1-2 \mathrm{~h}$ and can be considered as detection time for this method. As mentioned in Section 2, the specificity of coliform detection is achieved in this experiment by using a commercial coliform specific growth media similar to that used in most of the traditional commercial coliform detection methods. 

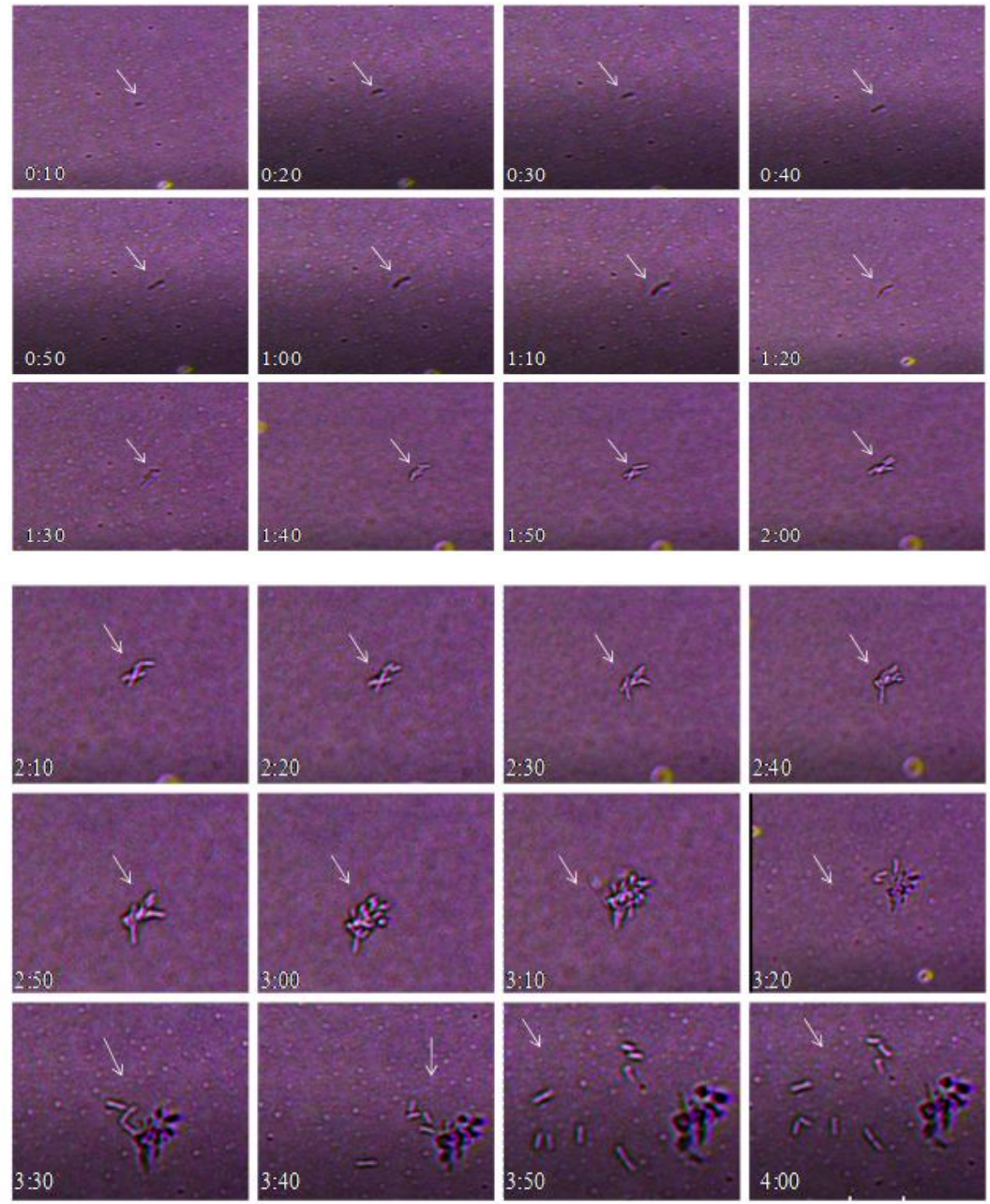

Figure 2. Bacterial multiplication observed over a period of $4 \mathrm{~h}$ at an interval of $10 \mathrm{~min}$ (H:min).

In this paper we aim to demonstrate the design of a test for coliforms in drinking water that can be completed in one hour. The device will need to be designed to be portable with the ability to transmit results to an online database, or to a user's phone. These additions and the proposed design of the whole system are discussed in some detail in the next sections. The concept rests on being able to detect bacterial growth quickly and correlating the amount of growth to the quantity of coliforms present in a sample. The work presented in the paper is to prove the concept using this methodology. The data shown in Figure 2 is used as evidence for the proof of concept on which we present our future design. The future work will be on developing a user-friendly, rugged prototype that can be used in the field. The subsequent section describes this proposed design in detail.

\section{Configuration of the Proposed Device}

The description given in the previous section concerns the preliminary investigation that was made to precede with the development of the design as shown in subsequent section. The device would comprise of an incubation chamber with a sample holder, a disposable sample tray, a microscope camera, and a microcontroller with software to track the bacterial growth at a single cell level in water (or food sample).

\subsection{Test Chamber}

The proposed design of the test chamber is given in Figure 3. It has a central, optically transparent area for viewing the splitting event of bacteria through the microscopic lens and recording by the 
camera module. The surface of this is treated with 3-aminopropyltriethoxysilane (APTES) to localized (immobilized) bacterial cells. This process has been developed inhouse. The test chamber is provided with an outer trough for holding selective growth media for target contaminant which provides a continuous supply of growth media to the cell localized at the central transparent area. This arrangement also prevents dehydration of the bacterial cell localized in the transparent area. During the test the pre-enriched sample processed in a custom-designed cartridge, as described in the subsequent section (Figure 4), is loaded in the test chamber through an input port. The test chamber is then placed in a sample holder of the device. The application of software will be developed to analyze at least 10 splitting events before predicting evidence of bacterial growth.

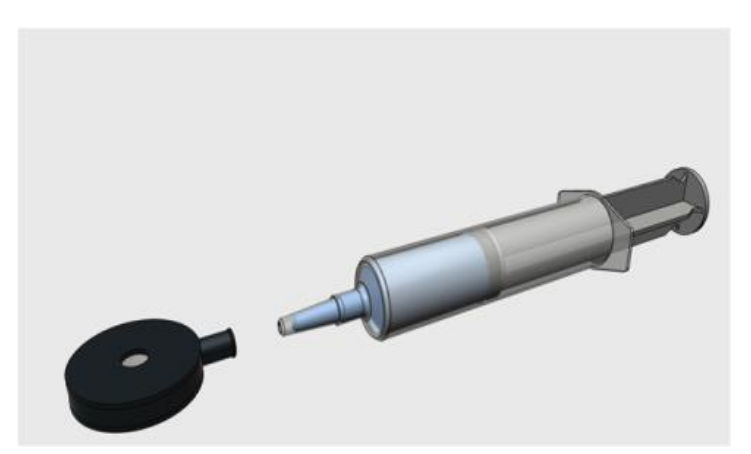

(a)

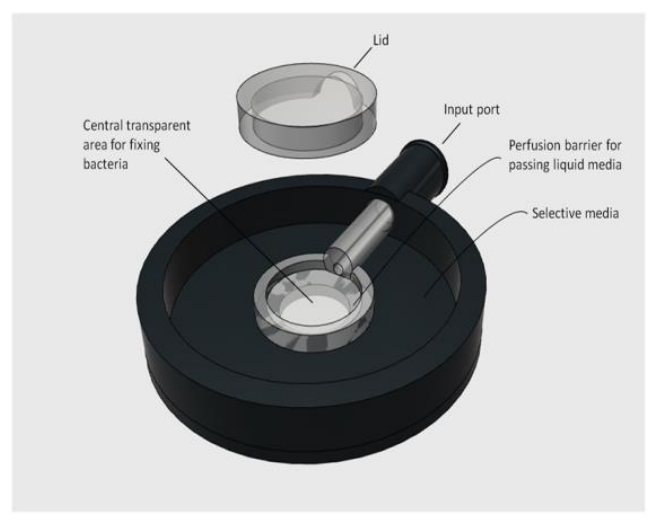

(b)

Figure 3. Internal design of proposed test chamber (a) Sample injection port (b) internal design of the test chamber.

The sample holder containing the pre-processed sample is then placed in an incubation chamber which maintains the temperature using a simple combination of a heating coil and a thermistor

a.

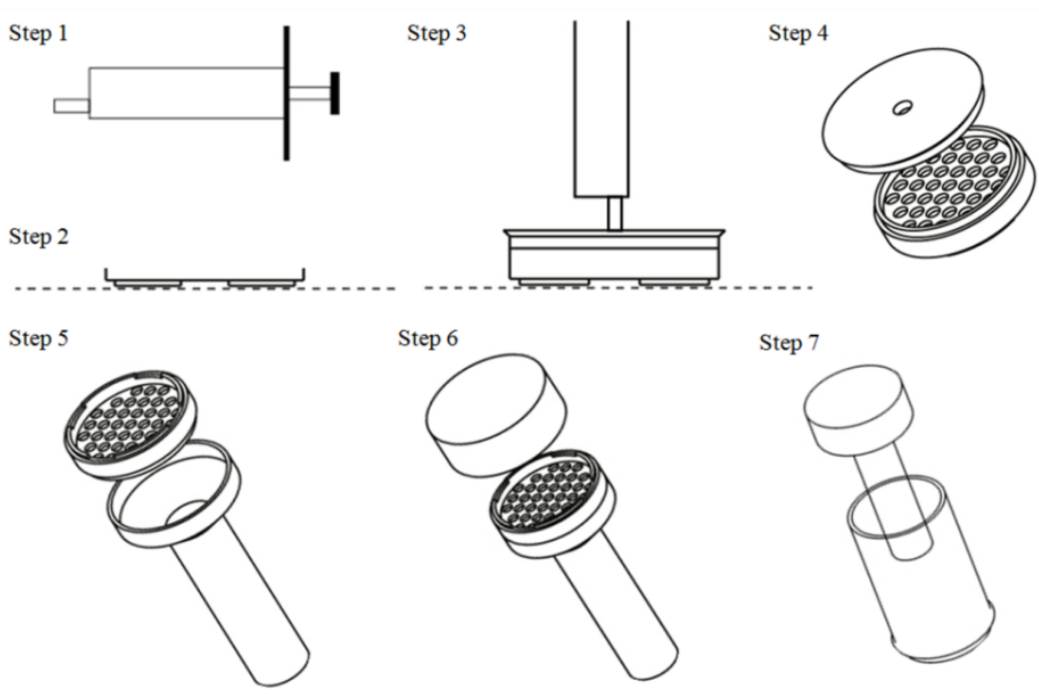

Figure 4. Cont. 
b.

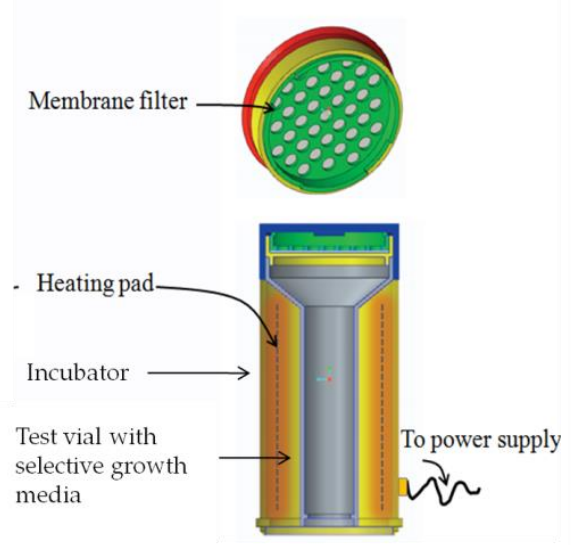

c.

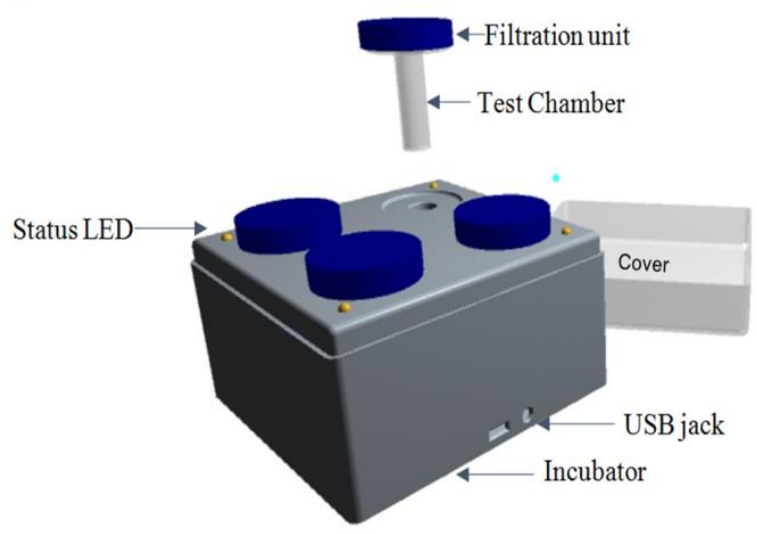

Figure 4. (a) Sample pre-enrichment test procedure: step 1: Collect $100 \mathrm{~mL}$ of water sample in a sterile disposable 2: set the disposable filter down on a flat surface; step 3: dispense the contents of the syringe into the filter allowing the water to drain out from underneath; step underneath; step 4: remove the syringe fixture part; step 5: unscrew the lid and place the disposable filter into the test chamber; step 6: close the lid back tightly; step 7: place the test chamber inside the single unit or multiple unit incubator. (b) Single unit incubator for incubatinga single sample and (c) multiple unit incubator for incubating multiple samples. LED: light-emitting diode; USB.

\subsection{Sample Pre-Enrichment}

Figure 4 illustrates the eventual test procedure to be performed while testing field samples. The steps involve passing $100 \mathrm{~mL}$ of water sample, and filtering through $0.45 \mu \mathrm{m}$ one-time use filter under pressure through a disposable syringe. The filter with the trapped bacteria would be enclosed in a disposable test chamber filled with a coliform selective growth medium. Finally, the test chamber can be placed in the portable incubator, which maintains a steady $37^{\circ} \mathrm{C}$ incubation temperature a for testing a single sample (Figure $4 \mathrm{~b}$ ) and for testing multiple samples (Figure $4 \mathrm{c}$ ).

\subsection{The Complete System}

The complete system is illustrated below in Figure 5, indicating the various components necessary for optimum bacterial growth, its capture, analysis, and transmission. The proposed prototype is $10 \mathrm{~cm}$ in height and $4 \mathrm{~cm}$ in width. The camera module, placed at the bottom, takes a number of images of the sample through the lens attachment at regular intervals. These images are stored in the microcontroller for analysis by making use of artificial intelligence tools-image analysis and neural networks. These give a result within $1 \mathrm{~h}$ from the start.

The test results can then be sent to the user's phone via Bluetooth or USB. A phone app could be provided to communicate this data to a central database allowing for other actions such as sending alerts, real-time mapping, and analysis. Moreover, considering the cost of lenses and electronic components used in the system, the initial cost of the device could be in the range of 140-280 United States Dollars (USD), whereas the consumable cost per test would be 0.7 USD, which is comparatively minimal when compared to different low-cost kits available in the market for bacterial contaminants which are in the range of 0.5 to 21 USD $[11,28]$. 


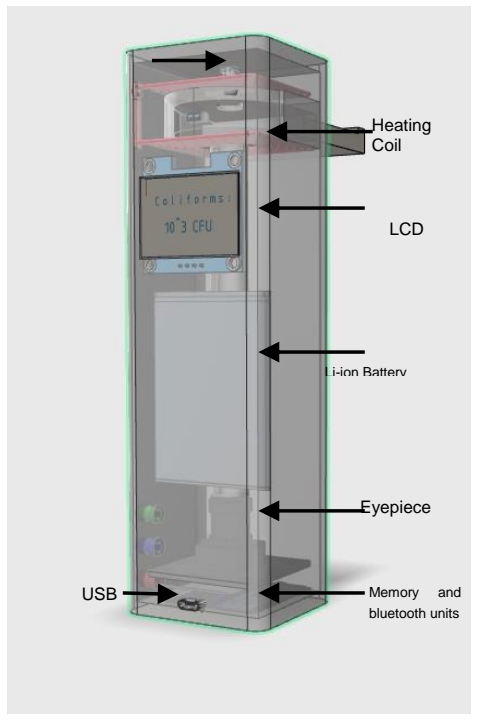

(a)

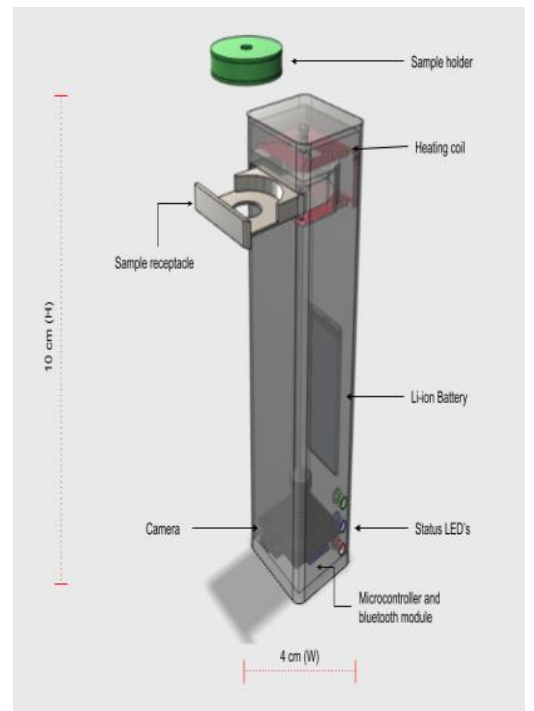

(b)

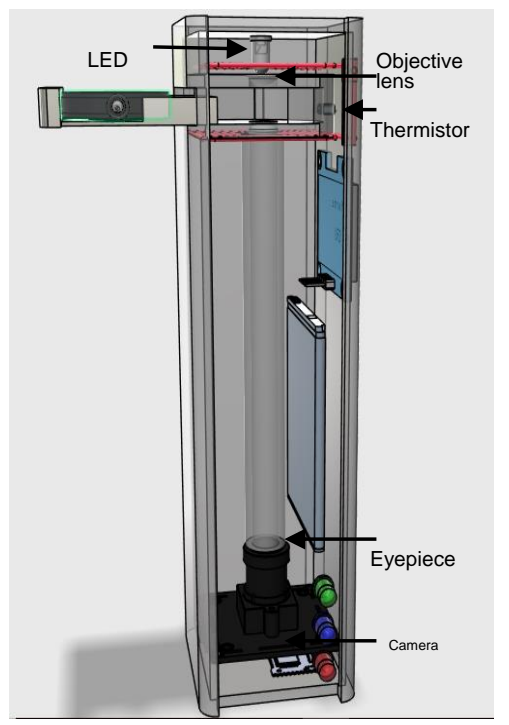

(c)

Figure 5. Design of proposed smart device. LCD: (a) Outer body of the device showing display, (b) test chamber holder within the device, (c) internal components of the device.

\section{The Decision System}

A BactImAS (Bacterial Image Analysis Software) is an open source software that can be used for cell segmentation and tracking, as well as storage, analysis, and visualization of acquired timelapse data. The detailed procedure and application of software is described by Mekterović et al, [29].

Developing an algorithm based on a convolution neural network to interpret the presence and absence of bacteria based on a splitting event will be the next step. The ANN (artificial neural network) system architecture shown in Figure 6 is suitable for this application. The software would be in the microcontroller system and would need to be trained using training images first. The system would analyze at least 10 splitting events before making the decision of bacterial growth.

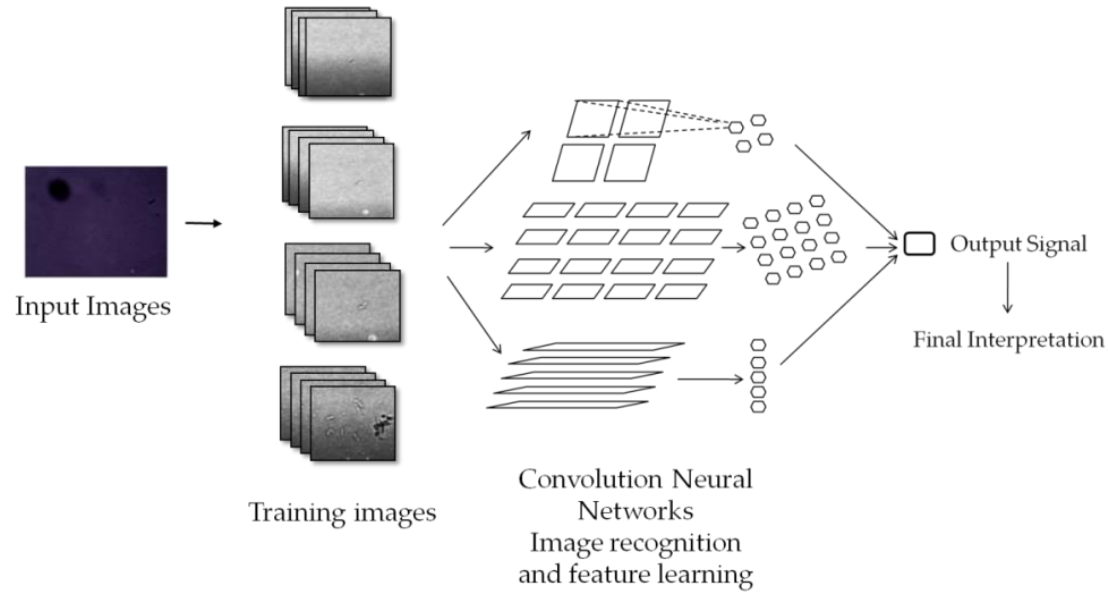

Figure 6. Neural network for tracking bacterial multiplication.

The images for training neural network were collected using time lapse microscopy at an interval of $10 \mathrm{~min}$. Figure 7 shows two sets of these images after a duration of $1 \mathrm{~h}$ each. Figure $7 \mathrm{a}, \mathrm{b}$ shows positive growth and Figure $7 \mathrm{c}$,d shows negative growth. The images processed by threshold application are used to count the increase in bacterial growth over time. A simple count of black pixels, after applying image thresholding would increase over time if growth of bacteria takes place. 


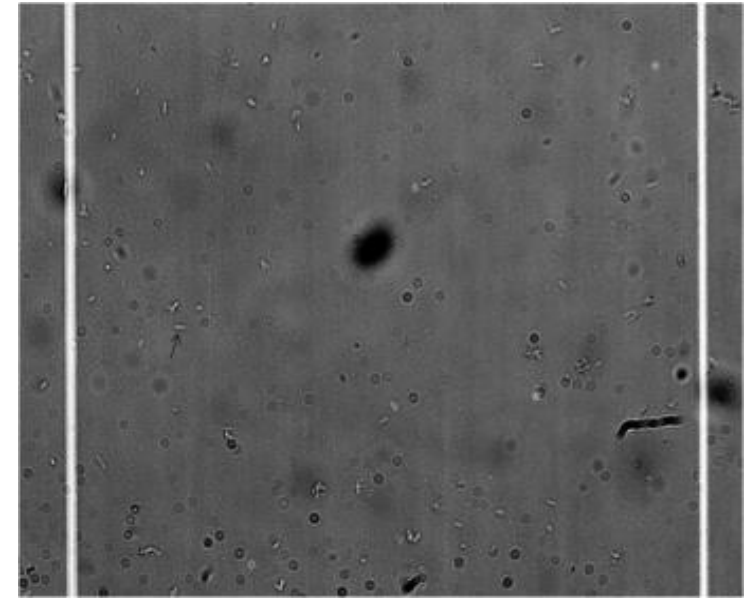

(a)

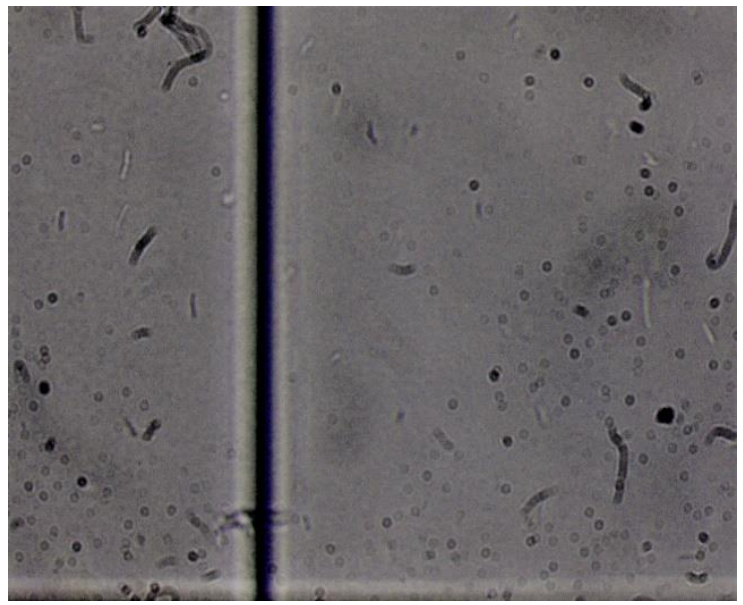

(c)

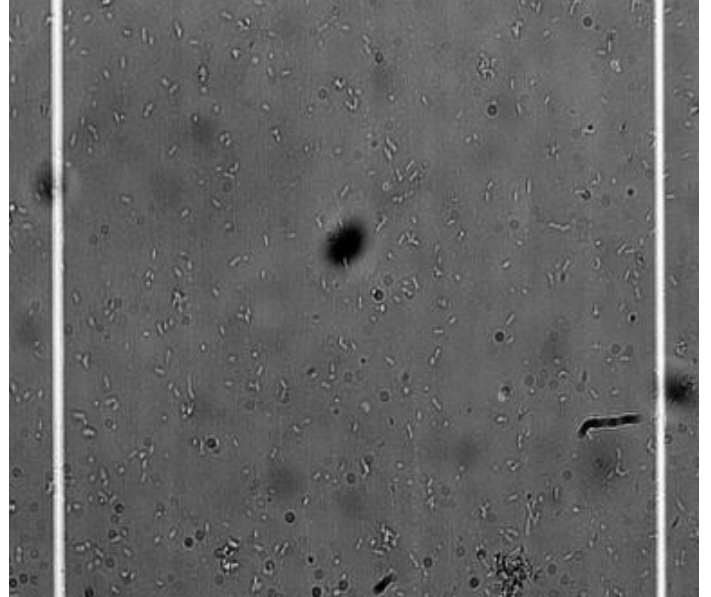

(b)

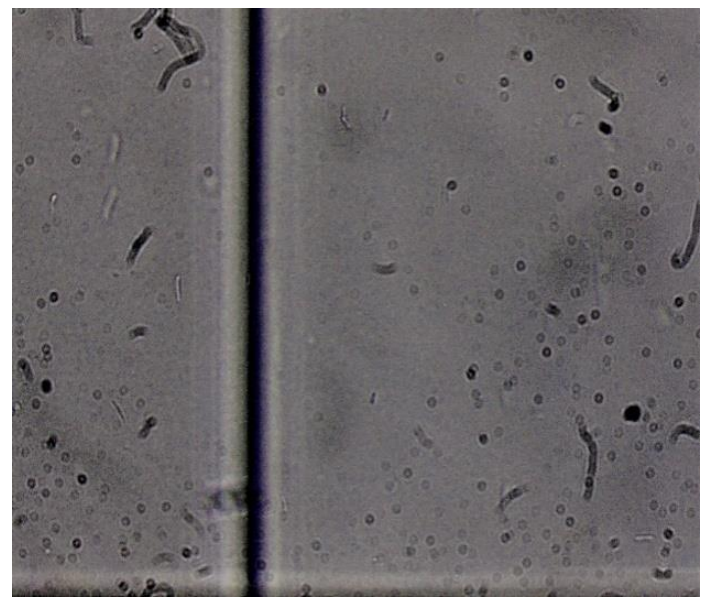

(d)

Figure 7. Training images: cell growth pattern of E. coli. (a) Positive images at $t=00: 00$ and (b) $t=01: 00 \mathrm{~h}$ Negative training image at (c) 00:00 and (d) 01:00. Magnification 450x.

\section{Conclusions}

This paper describes the concept and initial findings for the design of a smart system for early detection of bacteria in a water sample. The system is based on the application of microscope image processing and neural network for rapid detection of bacterial contaminants in a water sample. If successfully productized, the device will offer a number of advantages over bacterial testing kits currently available in the market. Results are obtained much faster (1-2 h) than the time required for traditional tests (24-48 h) and can be automatically geotagged and uploaded online. This makes it much easier to survey and monitor water points. Setup and per test costs are much lower than what is required for a fully functional lab and thus easy to use for in-field situations. This provides an easy way to monitor water sources in rural areas for fecal contamination, and appropriate measures can then be taken by the government or NGOs. It can greatly reduce the incidents and spread of waterborne diseases as it would allow the source of contamination to be determined much quicker than by traditional means.

Such a device could make it an invaluable tool during disaster relief efforts, when determining the location of clean water is pertinent. Similarly, using the device, water infrastructure providers can ensure that the outputs of their filtration systems are attaining the prescribed standards. The device could be equally useful in detecting pathogens in food and beverages, thus preventing incidences of food poisoning. It could also be suitable for testing the sterility of food items in food processing 
industries. Moreover, applying such rapid methods would help companies to have better and faster control of raw materials and final products resulting in savings in time and costs. Such rapid methods can also offer a better reactivity throughout the manufacturing process.

The investigation on bacterial cell biology is important for a number of fields, including genetic engineering and biotechnology, synthetic biology, infectious disease research, antibacterial development, molecular and systems biology, and clinical screening. Current methods in microbiology address bacteria at a population level, with measurements averaged over millions or billions of individual cells and thus difficult to monitor changes at the individual cell level. However, the device proposed can do bacterial analysis at the single cell level and thus will provide more detailed information such as cell variation, dynamic response profiles, spatial information, and morphological features of bacteria in different environments and thus will be highly beneficial to academic and research institutes.

We present here proof of concept; however, more research is still required to make such an innovation acceptable in the market for field testing. To take it further, the next steps in this direction for the research team include testing the concept with real water samples to test the efficiency of the specificity of the system and validate the process as well as device prototyping and testing the data analytics system.

Author Contributions: R.P. conceived of the presented idea, design and performed experiment, studied different aspects of project, wrote the manuscript with support of T.A., S.L. designed the device and performed all electronic work required during the experiment. S.R. developed the theory of machine learning for bacteria detection, supervised the findings of this work. T.A. writted the manuscript, verified the analytical methods, technical inputs. All authors discussed the results and contributed to the final manuscript. All authors have read and agreed to the published version of the manuscript.

Funding: This research received no external funding.

Conflicts of Interest: The authors declare no conflict of interest.

\section{References}

1. Ashbolt, N.J. Microbial contamination of drinking water and human health from community water systems. Curr. Environ. Health Rep. 2015, 2, 95-106. [CrossRef] [PubMed]

2. Parsai, A.; Rokade, V. Water Quality Monitoring Infrastructure for Tackling Water-Borne Diseasesin the State of Madhya Pradesh, India, and Its Implication on the Sustainable Development Goals (SDGs). In The Relevance of Hygiene to Health in Developing Countries; Potgieter, N., Hoffman, A.T., Eds.; IntechOpen: London, UK, 2019. [CrossRef]

3. Holm, R.; Singini, W.; Gwayi, S. Comparative evaluation of the cost of water in northern Malawi: From rural water wells to science education. Appl. Econ. 2016, 48, 4573-4583. [CrossRef]

4. Tortajada, C.; Biswas, A.K. Achieving universal access to clean water and sanitation in an era of water scarcity: Strengthening contributions from academia. Curr. Opin. Environ. Sustain. 2018, 34, 21-25. [CrossRef]

5. Kuylenstierna, J.L.; Björklund, G.; Najlis, P. Sustainable water future with global implications: everyone's responsibility. In Natural Resources Forum; Blackwell Publishing Ltd.: Oxford, UK, 1997; Volume 21, pp. 181-190.

6. Batchelor, C.H.; Rama Mohan Rao, M.S.; Manohar Rao, S. Watershed development: A solution to water shortages in semi-arid India or part of the problem? Land Use Water Resour. Res. 2003, 3, 1-10. [CrossRef]

7. Hanchett, S.; Akhter, S.; Khan, M.H.; Mezulianik, S.; Blagbrough, V. Water, sanitation and hygiene in Bangladeshi slums: An evaluation of the WaterAid-Bangladesh urban programme. Environ. Urban. 2003, 15, $43-56$.

8. Osborn, D.; Cutter, A.; Ullah, F.; Universal Sustainable Development Goals. Understanding the Transformational Challenge for Developed Countries. Report of a Study by Stakeholder Forum. May 2015. Available online: https://sustainabledevelopment.un.org/content/documents/1684SF_-_SDG_Universality_ Report_-_May_2015.pdf (accessed on 10 December 2019).

9. Martin, N.H.; Trmčić, A.; Hsieh, T.H.; Boor, K.J.; Wiedmann, M. The evolving role of coliforms as indicators of unhygienic processing conditions in dairy foods. Front. Microbiol. 2016, 7, 1-8. [CrossRef] 
10. Odonkor, S.T.; Ampofo, J.K. Escherichia coli as an indicator of bacteriological quality of water: An overview. Microbiol. Res. 2013, 4. [CrossRef]

11. Tallon, P.; Magajna, B.; Lofranco, C.; Leung, K.T. Microbial indicators of faecal contamination in water: A current perspective. Water Air Soil Pollut. 2005, 166, 139-166. [CrossRef]

12. Bain, R.B.; Elliott, M.; Matthews, R.; Mcmahan, L.; Tung, R.; Chuang, P.; Gundry, S. A summary catalogue of microbial drinking water tests for low and medium resource settings. Int. J. Environ. Res. Pub. Health 2012, 9, 1609-1625. [CrossRef]

13. Gunda, N.S.K.; Naicker, S.; Shinde, S.; Kimbahune, S.; Shrivastava, S.; Mitra, S. Mobile water kit (MWK): A smartphone compatible low-cost water monitoring system for rapid detection of total coliform and E. coli. Anal. Methods 2014, 6, 6236-6246. [CrossRef]

14. Rompré, A.; Servais, P.; Baudart, J.; De-Roubin, M.R.; Laurent, P. Detection and enumeration of coliforms in drinking water: Current methods and emerging approaches. J. Microbiol. Methods 2002, 49, 31-54. [CrossRef]

15. Warren, L.S.; Benoit, R.E.; Jessee, J.A. Rapid enumeration of Fecal Coliforms in water by a colorimetric beta-galactosidase assay. Appl. Environ. Microbiol. 1978, 35, 136-141. [PubMed]

16. Lewis, C.L.; Craig, C.C.; Senecal, A.G. Mass and density measurements of live and dead Gram-negative and Gram-positive bacterial populations. Appl. Environ. Microbiol. 2014, 80, 3622-3631. [CrossRef] [PubMed]

17. Law, J.W.; Ab Mutalib, N.S.; Chan, K.G.; Lee, L.H. Rapid methods for the detection of foodborne bacterial pathogens: Principles, applications, advantages and limitations. Front. Microbiol. 2015, 5, 770. [CrossRef] [PubMed]

18. Molina, F.; López-Acedo, E.; Tabla, R.; Roa, I.; Gómez, A.; Rebollo, J.E. Improved detection of Escherichia coli and coliform bacteria by multiplex PCR. BMC Biotechnol. 2015, 15, 48. [CrossRef]

19. Priest, D.G.; Tanaka, N.; Tanaka, Y.; Taniguchi, Y. Micro-patterned agarose gel devices for single-cell high-throughput microscopy of E. coli cells. Sci. Rep. 2017, 7, 17750. [CrossRef]

20. Joyce, G.; Robertson, B.D.; Williams, K.J. A modified agar pad method for mycobacterial live-cell imaging. BMC Res. Notes 2011, 4, 73. [CrossRef]

21. Fernández-Miranda, E.; Majada, J.; Casares, A. Efficacy of propidium iodide and FUN-1 stains for assessing viability in basidiospores of Rhizopogonroseolus. Mycologia 2017, 109, 350-358. [CrossRef]

22. Gao, P.; Sun, C.; Li, Y.; Zou, X.; Wu, X.; Ling, Y.; Luan, C.; Chen, H. Vital staining of bacteria by sunset yellow pigment. Pol. J. Microbiol. 2017, 66, 113-117. [CrossRef]

23. Haines, A.M.; Tobe, S.S.; Kobus, H.; Linacre, A. Finding DNA: Using fluorescent in situ detection. Forensic Sci. Int. Genet. Suppl. Ser. 2015, 5, e501-e502. [CrossRef]

24. Haines, A.M.; Tobe, S.S.; Kobus, H.; Linacre, A. Duration of in situ fluorescent signals within hairs follicles. Forensic Sci. Int. Genet. Suppl. Ser. 2015, 5, 175-176. [CrossRef]

25. Mishra, M.; Chauhan, P. Applications of Microscopy in Bacteriology. Microsc. Res. 2016, 4, 1-9. [CrossRef]

26. World Health Organization (WHO). Guidelines for Drinking-Water Quality; World Health Organization: Geneva, Switzerland, 2011.

27. Pettipher, G.L.; Mansell, R.; McKinnon, C.H.; Cousins, C.M. Rapid membrane filtration-epifluorescent microscopy technique for direct enumeration of bacteria in raw milk. Appl. Environ. Microbiol. 1980, 39, 423-429. [PubMed]

28. Patil, R.; Levin, S.; Halery, N.; Gupta, I.; Rajkumar, S. A smartphone-based early alert system for screening of coliform contamination in drinking water. J. Microbiol. Biotechnol. Food Sci. 2019, 539-547. [CrossRef]

29. Mekterović, I.; Mekterović, D. BactImAS: A platform for processing and analysis of bacterial time-lapse microscopy movies. BMC Bioinform. 2014, 15, 251. [CrossRef]

(C) 2019 by the authors. Licensee MDPI, Basel, Switzerland. This article is an open access article distributed under the terms and conditions of the Creative Commons Attribution (CC BY) license (http://creativecommons.org/licenses/by/4.0/). 